\title{
Visibility and Rhetoric: The Power of Visual Images in Norman Rockwell's Depictions of Civil Rights
}

\author{
Victoria Gallagher \& Kenneth S. Zagacki
}

This essay demonstrates how visual works of art may operate rhetorically to articulate public knowledge, to illustrate the moral challenges facing citizens, and to shape commemorative practices, through an analysis of Norman Rockwell's civil rights paintings of the 1960s. By examining the rhetorical aspects of these paintings, including their form and composition, the essay demonstrates the power of visual works of art to evoke common humanity in three significant ways: (1) disregarding established caricatures; (2) creating recognition of others through particularity; and (3) depicting material aspects of American society, thereby reminding viewers that abstract political concepts are always relative to the individuals or groups whose lives are most directly influenced by their presence or absence.

Keywords: Visual Rhetoric; Norman Rockwell; Visibility; Civil Rights

Authors and scholars interested in the civil rights movement of the 1950s and 1960s are in general agreement that mediated visual images aided in the pace of social change sought by movement activists. For instance, David Halberstam, who covered the movement as a journalist, argues that one of the essential things Martin Luther King, Jr. (and, by association, the civil rights movement) accomplished was making visible the realities of segregation through the popular media:

King offered reporters two absolutely irresistible things: ongoing confrontation of a high order and almost letter-perfect villains. In that sense he was more than just a master manipulator; he was, in the television age, as great a dramatist of midcentury America as Arthur Miller or Tennessee Williams. ${ }^{1}$

But visual artists also responded to the dramatic events, constructing what Gretchen Sullivan-Sorin calls "their own visual history. Mainstream magazines ...

\footnotetext{
Victoria Gallagher and Kenneth S. Zagacki are Associate Professors in the Department of Communication at North Carolina State University. Correspondence to: Victoria Gallagher, Department of Communication, North Carolina State University, Raleigh, NC 27695-8104, USA. Email: gallagher@social.chass.ncsu.edu; kszagack@ social.chass.ncsu.edu.
} 
brought people face-to-face with the courage of demonstrators" using re-printed paintings to make their case. For instance, as Sullivan-Sorin notes, Norman Rockwell's painting “The Problem We All Live With" "exposed another national shame to the light of public opinion." " Not recognized as a painter who was politically engaged early in his career, Rockwell nevertheless maintained a longstanding interest in civil rights. As early as 1946, he had supported the integration of a sorority at the University of Vermont and corresponded with the Bronx Interracial Conference concerning race relations. ${ }^{3}$ Still, the bulk of Rockwell's pictures, the most popular of which often adorned the covers of the Saturday Evening Post, revealed an idyllic America of wholesome holiday celebrations, sporting events, and family gatherings. As Laurie Norton Moffatt puts it, Rockwell appeared to share with the publishers of the Saturday Evening Post "a morality based on popular values and patriotism, a morality that yearns above all for goodness to trump evil." 4

By the 1960s, however, Rockwell had decided to undertake dramatic shifts in his painting, documenting the racial discord in American society as it emerged over civil rights and desegregation. Such changes required parting ways with the Saturday Evening Post, the editors of which, according to the art critic Karal Ann Marling, forbade Rockwell from painting "colored people" on its covers "unless they were performing menial tasks." Instead, Rockwell produced three paintings dealing with desegregation and civil rights, published in the national magazine Look. As Rockwell biographer Laura Claridge points out, this emphasis on issues of race "most engaged Rockwell's interest, and he would produce what were arguably some of his most effective, moving paintings for the inside [of a magazine], not the cover." ${ }^{\text {" }}$ At the time Rockwell's paintings were published, Look was in the midst of its "golden years" (1954-1964), having become well-known for its documentary photography and its coverage of politically charged social topics such as the changing roles of women and racial tension in the South (in 1956, the magazine published the confession of Emmitt Till's killers). Given Look's bi-weekly distribution and its emphasis on social and political subjects, perhaps Rockwell believed his paintings would reach a wider if not a more politically-sophisticated audience.

In “The Problem We All Live With” (Figure 1), of 1964, Rockwell recorded his interpretation of the first day Ruby Bridges attended the formerly all-white William Frantz Public School, in New Orleans, Louisiana, during the fall of 1960, as she was accompanied by U.S. marshals who tried to protect her from an angry white mob protesting the school's desegregation. Rockwell's version was probably influenced by a story he had heard from the psycho-therapist Robert Coles and a description of the incident in John Steinbeck's Travels with Charlie. (Both Coles and Steinbeck had witnessed the events at William Frantz first-hand.) According to Marling, "The Problem" was part of a Look magazine issue devoted to the question of "How We Live." Included in the series of stories about middle-class influence, the housing boom, and the ongoing competition between modern and traditional design were brief discussions of "ghettoization," token integration, and white flight, and one paragraph examined the practice of denying equal opportunity in housing to members of minority groups. ${ }^{7}$ 


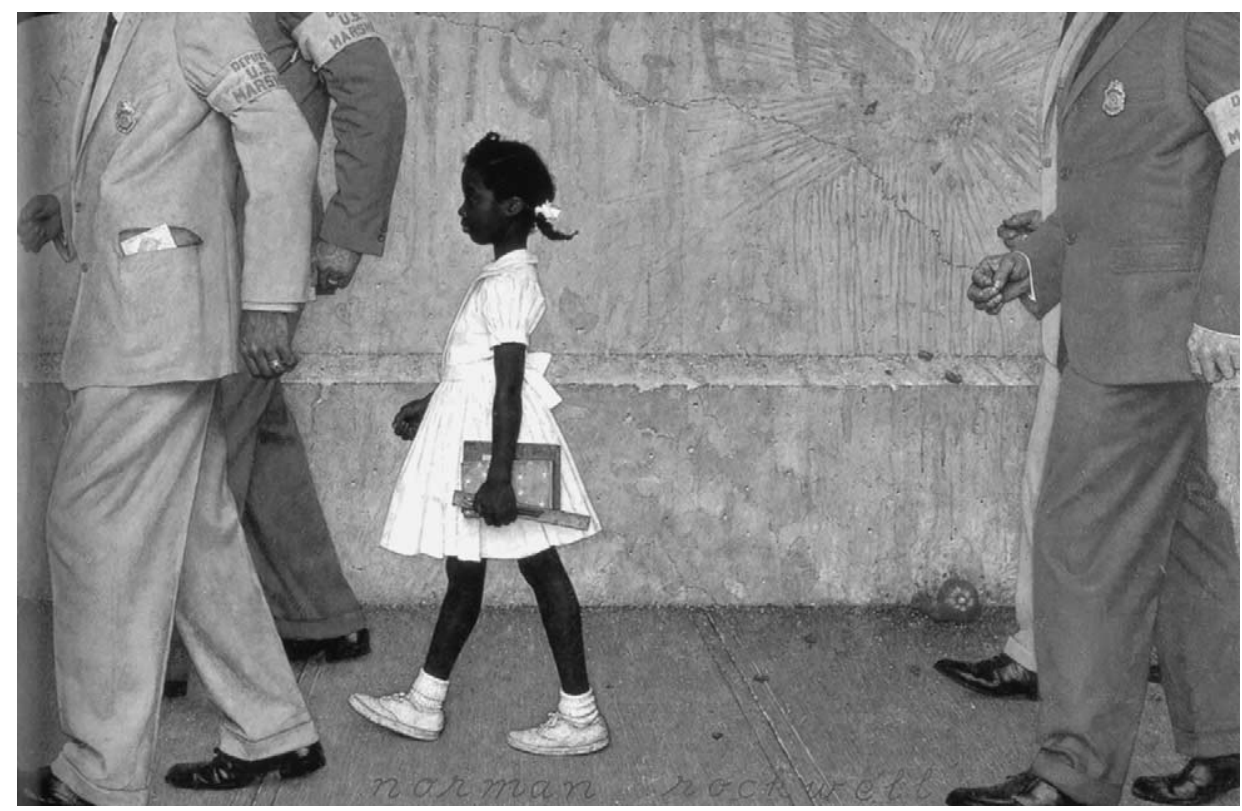

Figure 1. "The Problem We All Live With" (1964). Reproduced with permission.

In "Murder in Mississippi" (also known and labeled in Look as "Southern Justice"; Figure 2), from 1965, Rockwell rendered an incomplete oil sketch of the killing of Michael Schwerner, Andrew Goodman, and James Chaney, the young civil rights activists who had traveled to Philadelphia, Mississippi, in the summer of 1964 as part of a large contingent of volunteers determined to break the back of segregation - and in particular the state's intimidation of black voters. Originally, Rockwell submitted the sketch to Look's art director, who recommended it be published. Rockwell insisted that the director allow him to produce a finished painting, but he was told that everyone at the magazine preferred the sketch, the loose brushwork of which "delivered more impact than the finished oil." published.

Finally, in "New Kids in the Neighborhood" (Figure 3), printed in 1967, Rockwell created a fictional scene in which two black siblings and their fluffy white cat, whose family has just moved into a white suburb - their furniture lined up on the lawn behind them, next to a moving truck being emptied by a man with dark skin and dark hair - stand face to face with a collection of curious white kids from the neighborhood and their equally curious dog. The picture accompanied an investigative article on black settlement in the suburbs. ${ }^{9}$

Despite recognition of the persuasive power of visual images such as these, rhetorical critics have largely ignored them, focusing instead on the speeches of civil rights leaders and speakers in their analyses of civil rights-related rhetoric. Our purpose in this paper is to address this gap by showing how Rockwell's paintings worked rhetorically to establish visibility - to make visible people, attitudes, and 


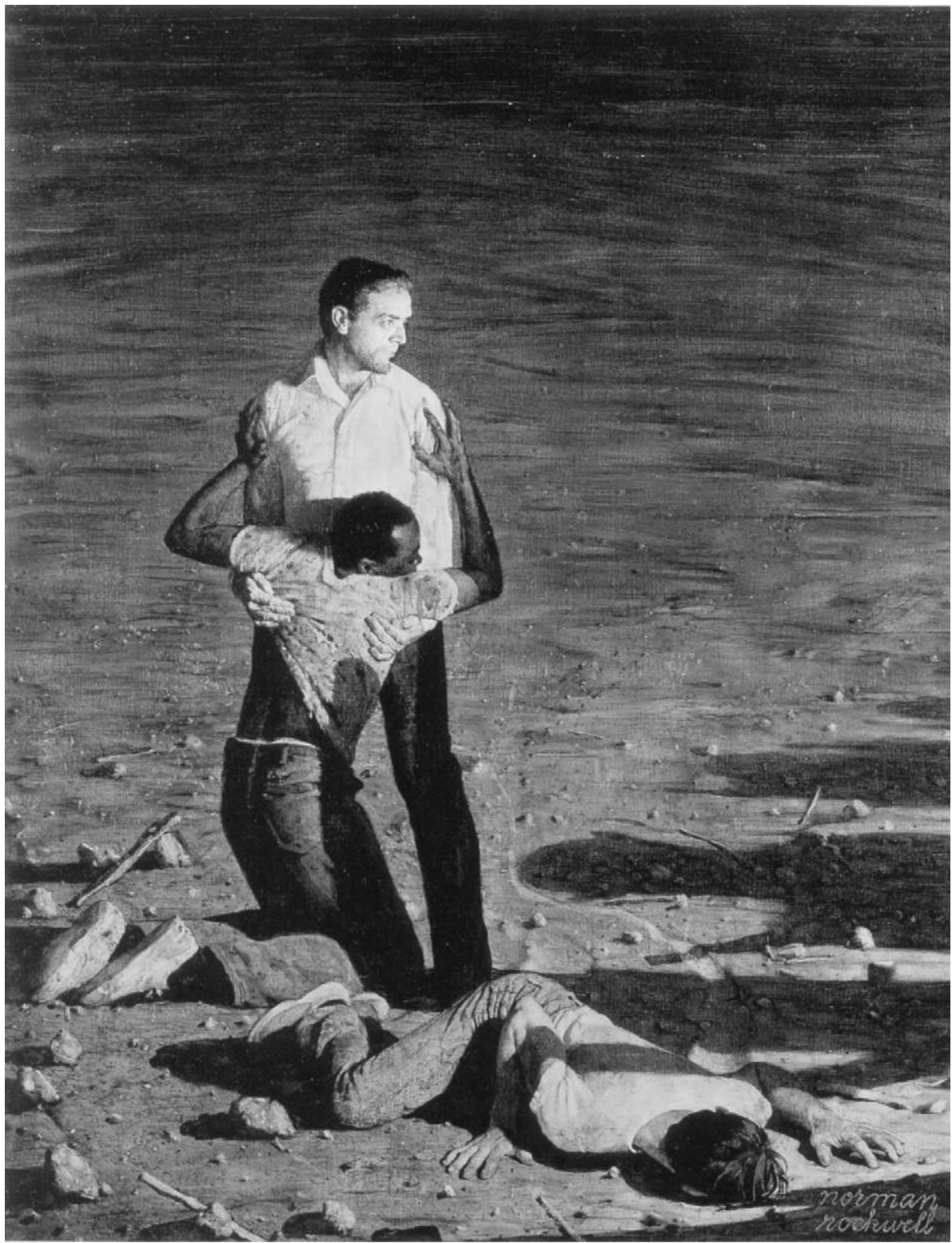

Figure 2. "Murder in Mississippi" (1965). Reproduced with permission.

ideas in the context of the struggle over civil rights in America. By examining these visual works of art from a rhetorical perspective, we are also able to demonstrate how visual images can work both to articulate and to shape public knowledge through offering interpretive and evaluative versions of who does what to whom, when, and where. For in these pictures, Rockwell functioned much like an epideictic orator, visualizing human virtue and vice and thus proving his subjects worthy of praise or blame. He presented visual arguments and information that helped demonstrate that 


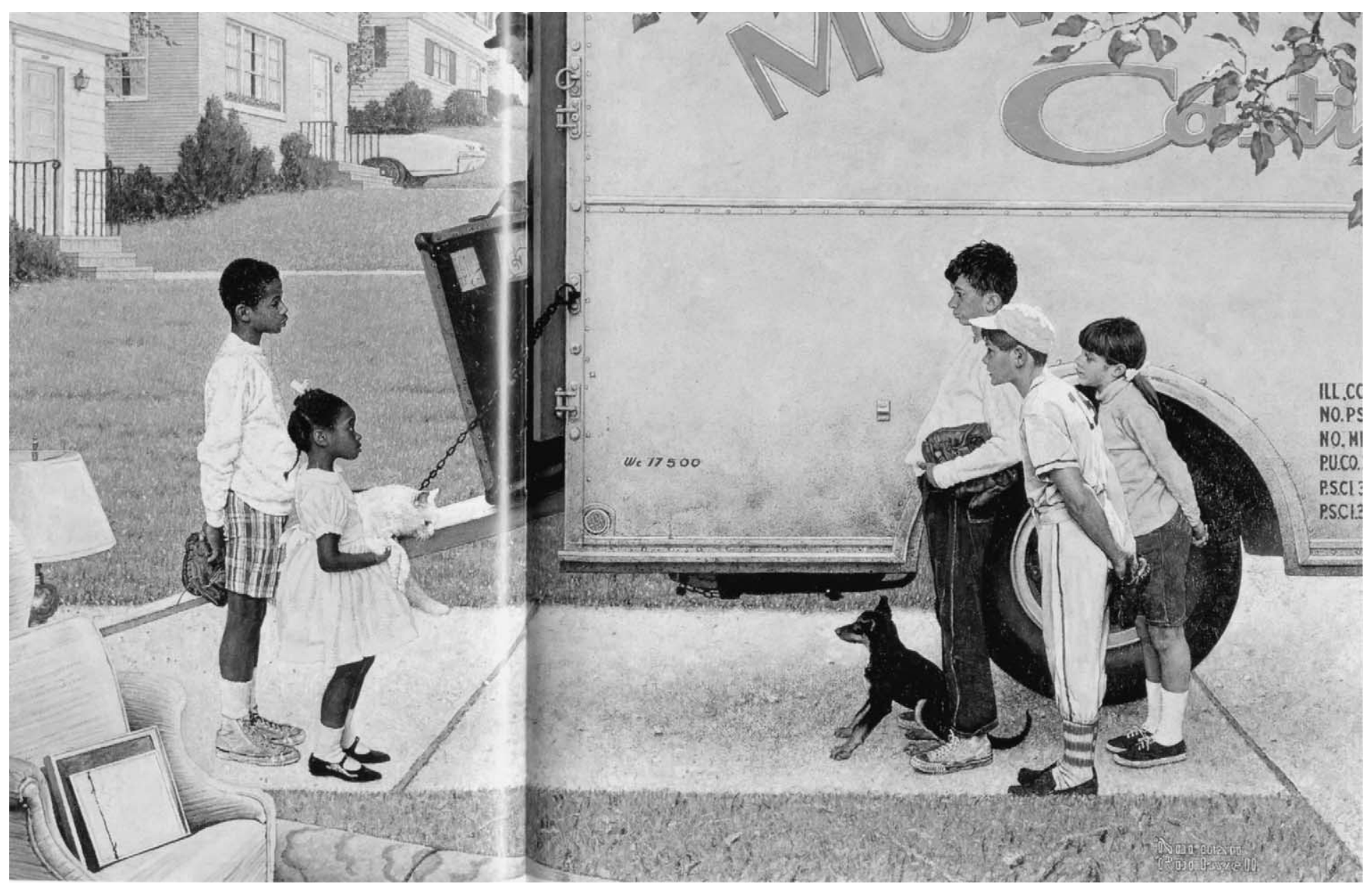

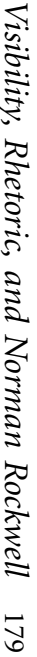

Figure 3. "New Kids in the Neighborhood" (1967). Reproduced with permission. 
certain individuals possessed a virtue or, conversely, that they were vicious racists or somehow implicated in the act of racism as a result of their apathy or acquiescence. As Lester Olson has written about the epideictic function of Rockwell's famous "The Four Freedoms for Which We Fight" posters from World War II, the artist manipulated "People's aesthetic sensibilities ... for pragmatic ends. Visualization of the praiseworthy or the blameworthy allows for the union of aesthetics and society, since a people's aesthetic artifacts can both reflect and reform social action." ${ }^{\prime 10}$

Of course, we recognize that the choice of Rockwell limits our analysis to visual images authored by a white agent, working on behalf of a white-owned national publication. But that is precisely the point. Our thesis is that these paintings functioned to evoke the common humanity of blacks and whites by portraying - by making visible - the abstract forms of civic life in the lived experience of individual citizens, both black and white. That these images did so at a time when much whiteauthored rhetoric depicted black people as inferior and/or as a separate class of beings is central to their rhetorical significance. ${ }^{11}$ But equally important to our understanding of Rockwell as a rhetorical agent is the turn he took in the 1960s, when he moved away from calming pictures of nostalgia and painted newer, discomforting images of democratic struggle in the face of racial aggression. According to Moffatt, for Rockwell "to take his affectionate following and turn to these difficult and topical subjects helped the public ask questions and think about what was going on in the world around them. ${ }^{12}$

By examining the rhetorical aspects of these paintings, including their form and composition, we demonstrate that Rockwell's paintings achieve rhetorical significance in three ways. First, they evoke common humanity by visually disregarding established caricatures, making African Americans visible in ways that negated the inferior character tropes that were the norm of the white-authored advertisements, movies, and public discourse of the period. Second, Rockwell's paintings evoked common humanity by creating recognition of others through particularity. Rockwell visualized the tremendous obstacles confronting blacks in America as they tried to live life in all of its particularity - as practitioners of free speech, as dedicated school children, and as unassuming neighbors - and thereby investigated particular modes of moral action in the contemporary world. Finally, in the 1960s, the idea of democracy may have taken on certain abstract meanings for whites who frequently took it for granted or who had come to recognize democracy at work in the idealistic renderings of Rockwell himself. However, Rockwell's civil rights paintings, which depicted racial disharmony as a material aspect of American society, reminded viewers that abstract political concepts were always relative to the individuals or groups whose lives were most directly influenced by their presence or absence.

We begin with a description of visual rhetoric and representations of race. We then examine the strategies of visibility within each of Rockwell's paintings: disregarding established caricatures by evoking shared humanity, creating recognition of others through particularity, and making abstract concepts knowable. We conclude with a discussion of the implications of this analysis - particularly in terms of the pedagogical and display functions of visual works of art-for the growing body of 
literature on visual eloquence and the rhetoric of commemorative practices. Our investigation demonstrates the powerful ideological and commemorative potential of popular works of art that deal with the complexities of race. We show how such works function rhetorically, providing the resources to challenge viewers' established beliefs and to encourage viewer participation in the experiences of others.

\section{Visual Representation and Race}

The role that visual rhetoric played in the civil rights movement of the 1950s and 1960s has been taken up by Kathleen Hall Jameson, who, while she acknowledges the impact of Martin Luther King, Jr.'s moving words, argues that the movement "was catalyzed not by eloquent words but by eloquent pictures." ${ }^{13}$ She points to media images that contributed to each legislative and political victory in the movement, including the introduction of the Civil Rights Act in 1963, its passage in 1964, and the introduction of the Voting Rights Act in 1965. Jamieson argues that a link between eloquence and visual images has long existed in rhetorical theory. She quotes Francis Bacon: "[I]t is the office of Rhetoric to make pictures of virtue and goodness so that they might be seen," and she traces the shift in 20th-century rhetorical practice from using words to stimulate an audience's visual imagination to using visual images themselves with the words of a speaker serving almost as a caption. ${ }^{14}$ But how is it that visual images can have such an impact? What is it about making something visible that is so rhetorically powerful? In what ways do visual images work rhetorically to open up or close down ways of seeing?

In her examination of the roots of the culture of segregation in the United States, Grace Elizabeth Hale both addresses these questions and reveals certain problems in visual representations of race. She demonstrates how visual images regarding race during the time period 1890-1940 were central to the establishment of the culture of segregation in the South to begin with:

The desire to mark racial differences as a mass identity, as white versus "colored," converged with the means to create and circulate the spectacle. And spectacle, the power of looking, was different from narrative, the power of telling. A picture, a representation, could convey contradictions and evoke oppositions like white racial supremacy, white racial innocence, and white racial dependency more easily and persuasively than a carefully plotted story. ${ }^{15}$

Thus, while images like Rockwell's civil rights paintings may visualize the common humanity of audiences by interrogating established caricatures and overturning inferior, threatening, or otherwise demeaning character tropes, Hale's work shows how the distribution of visual images helped to create such caricatures in the first place, and thereby worked to mask oppressive power relationships within the culture:

But the "people who think of themselves as white" - a naming James Baldwin crafted to render visible this process of racial making - also produced their own mass cultural identity across divisions of class, gender, region, and religion and rendered its whiteness invisible at the same time. Focusing on the visible, they attempted to control both the geographical and representational mobility of 
nonwhites. African Americans were clearly inferior in the South because they occupied inferior spaces like Jim Crow cars, often literally marked as colored, and across the nation because they appeared at fairs, in advertisements, and in movies as visibly inferior characters. Yet whites made modern racial meaning not just by creating boundaries but also by crossing them. Containing the mobility of others allowed whites to put on blackface, to play with and project upon darkness, to let whiteness float free. These transgressions characterized and broadened modern whiteness, increasing its invisibility and its power. ${ }^{16}$

Hale's work illuminates the rhetorical complexities and ironies of visual representations of race. ${ }^{17}$ Yet visual images also contribute to an unfolding process of articulation and interaction that enables an "other" to become known as a human being with specific and acceptable human traits and qualities. As the photographer Pirkle Jones has said about pictures he and his wife, Ruth-Marion Baruch, took of the Black Panthers in the 1960s, "[W]e showed them 'as human beings,' with all of their admirable traits and desires." 18 This contrasted with the often one-dimensional portrayals of the Black Panther movement as violent anarchists promulgated in the press during that period, which also informed the racist attitudes of many whites. The process of identifying the other with the viewer negates the subject as different inasmuch as the traits and qualities seem to represent the nature of all members of a society. However, in Rockwell's paintings, as we shall demonstrate, if any person or group is seen as transgressing or violating social principles and therefore as constituting a real threat to social order, it is the hordes of whites that he often left either implied or cast more directly in twisted, dark, alien-looking shadows, lurking just outside or at the borders of his paintings.

Similarly, visual images in the popular media have tended to "naturalize" the accepted experience of blacks as reality and disguise the social context in which institutions such as slavery or Jim Crow developed. However, images also may disclose particular aspects of human beings as they confront the world in the hereand-now. To illustrate this dual quality of visual images, consider David Hickey's critique of The Problem, in which he takes Rockwell to task for generalizing from particulars "in the manner of a social scientist rather than particularizing generalities as he had always done." 19 Ruby Bridges' response to Rockwell's painting of her directly refutes Hickey's reading, underscoring the argument we make in this paper, namely that Rockwell's painting worked to disclose particularity to the viewer. In distinguishing between the rhetorical function of the painting and the news coverage of her experience she said: "That picture is about me.... What you see in the news is about the trouble on the street." ${ }^{20}$ What Hickey apparently failed to take into account is the larger context of visual representations of race, in which visual images have often served to categorize racial experience in terms such as "the slave experience" or the "immigrant experience," thereby locating the suffering of blacks in the past in a way that has failed to impinge on contemporary white sensibilities. A rhetorical perspective, by contrast, focuses on how images interrogate viewers so as to invoke self-awareness about the conscious lived experience of the other. For instance, the viewer might have responded morally to the particular time and space in which the 
other found herself. As Hariman and Lucaites argue about the visualizing power of iconic photography, since the public is "a body of strangers constituted solely by the acts of being addressed and paying attention, it can only acquire self-awareness and historical agency if individual auditors 'see themselves' in the collective representations that are the material of public culture." ${ }^{21}$ Susanne Langer describes this central role of visibility in painting and sculpture: "It is only when an object exists in our lives for no other purpose than to be seen that we really look at it." ${ }^{\text {"2 }}$ At the same time, as Hariman and Lucaites point out, visual images "continually interpellate audiences and typically model preferred forms of response... [and] can structure consciousness in ways that are not reducible to determinations of influence on specific policy decisions." 23

Finally, a related and central function of pictorial rhetoric is the evocation of humanity by moving beyond abstract or idealistic categories to depictions of social experience that are recognizable to common audiences and that add moral import to the decisions or developments before them. As Michael Warner observes, "It is hard to imagine such abstract modes of being as rights-bearing personhood, species being, and sexuality, for example, without forms that give concrete shape to the interactivity of those who have no idea with whom they interact." 24 Hariman and Lucaites add:

Concepts such as citizenship, emotions such as love of country, acts such as public advocacy, and practices such as critical reflection can only be taken up by others if they also provide some basis for identification, some grounding in the positive content of lived experience. The abstract forms of civic life have to be filled in with vernacular signs of social membership. ${ }^{25}$

Certainly, much African American painting and sculpture operated rhetorically in this fashion, as art critic Richard Powell implicitly observes. Such artwork "raised the specter of inequality in a so-called American democracy, drew attention to the frightening truths about white-on-black violence, and focused on examples of endurance and moral tenacity in the face of these obstacles." ${ }^{26}$ We suggest that, although authored by a white agent, Rockwell's paintings nevertheless also "drew attention" to the concrete implications of racial "inequality" in "American democracy," to "white-on-black violence," and to "examples of endurance and moral tenacity" while answering the questions: What is the concrete relationship between civil rights and democracy? What would be the material conditions of granting civil rights? How would desegregation change the face of American schoolyards and neighborhoods? What role would freedom and tolerance play here?

\section{Black Images in White Minds}

\section{Disregarding Established Caricatures}

The subjects presented in Rockwell's "The Problem" and "New Kids" both subsume and disregard previously established caricatures of blacks as threatening, some of which were actually perpetuated by members of the large crowd that had gathered to harass Ruby Bridges as she entered William Frantz on her first day. ${ }^{27}$ According to 
Coles, angry white men, women, and children shouted, among other things, "Two, four, six, eight, we don't want to integrate!"28 Several police officers joined in the chanting. One middle-aged woman complained to Coles: "They're trying to bring a nigger kid into our school-it'll be over our dead bodies!"29 Another onlooker claimed that desegregation not only threatened the economic security of whites but also their physical safety:

It's all unfair, and that's why there comes a time when you just have taken so much, and now it's all come here to roost right in your own neighborhood, and they're coming at your own child's life, her school, and giving it to someone else, just because someone up there in Washington, D.C., says it's got to happen, and someone down here [a federal judge] goes along. ${ }^{30}$

When Rockwell portrayed his version of events at William Frantz four years later in "The Problem," he showed that what many of these whites considered to be a "problem" - racial desegregation, as embodied by the presence of Ruby — was not a problem at all. As we shall see, this was because Ruby and other black children like her, some of whom he also portrayed in "New Kids," were depicted as wholesome American children and, therefore, as no threat to anyone. In fact, while it remains unclear whether or not Rockwell was aware of it, black writers at the time argued that calling the racial conflict the "white problem" was a good deal more precise than calling it the "black problem." ${ }^{31}$ In the case of Rockwell's painting, the ambiguity allowed a viewer to open him or herself up to the work with the initial impression that this would be the usual depiction of the black problem, only to have to engage the racial bias that he or she also brought to the viewing. In short, Rockwell was challenging the way in which white America defined both the sources of racial conflict and the very nature of this conflict itself.

Thus, as both "The Problem" and "New Kids" demonstrated, life was going to be different for whites at the civic level of public education and in white suburbs. But Rockwell was arguing that this did not represent a threat like that described by the white protestor above - instead he argued visually that blacks desired not to take over or take away but to share mainstream white institutions, and that whites needed to accommodate them.

Indeed, the threats in at least two of Rockwell's civil rights paintings originate from sources other than the black subjects. If a "problem" existed, it was the menacing white mobs in "The Problem" and "Murder in Mississippi." The fearsome quality of many of these antagonists, which Rockwell implied in "The Problem" but represented a bit more directly through the menacing shadows of the killers (which appear to feature pointy ears and antennae-like protrusions) in "Murder in Mississippi," indicated that they were the true violators of American values, existing outside the boundaries of both the law and the established social order. Even the somewhat puzzled-looking white children in "New Kids" suggested a potential threat, if in fact it turned out that, like many of their real-life counterparts, these children and their parents resisted the movement of black families into suburban living spaces. 
On the other hand, the non-threatening nature of integration and, by association, of Negroes, was suggested, in part, by the unassuming way in which Rockwell presented Ruby in "The Problem." For example, he employed movement, posture, and contrasting colors to portray her apparent innocence, moral purity, and even moral defiance in the face of onrushing violence and, therefore, succeeded in highlighting the dangers implicit in the surrounding scene and the immorality of the white segregationist-racist position. As Claridge explains about "The Problem," the "massive impersonality" of the marshals, "benign but anonymous, contrasts" with Ruby's smallness.

The child walks with a combined stiffness and unnatural strut that belies her fright, and the preternatural whiteness of her dress against the deep glow of her skin not only announces the theme of the painting - it takes on a spiritual symbolism, as if challenging Americans to act any way other than morally righteous.... The letters "KKK" are carved on the wall in the left part of the picture, and, as if to counterbalance the ugliness of those initials, Rockwell has painted NR+MP in a tiny heart at the bottom, a love note to the wife who has emboldened him. ${ }^{32}$

Similar observations could be made about "Murder in Mississippi," where, as we shall see, the civil rights workers appear as heroic soldiers against the dark, battle-scarred landscape. One of them stands defiantly in the face of the implied murderous white crowd, his head awash in a (heavenly?) glow of light. The use of color to envision the moral innocence and non-threatening nature of blacks in "New Kids" also creates a kind of ironic reversal. Here, Rockwell painted the dog black and grouped it with the white children, so that the blackness whites traditionally associated with evil or impurity was instead transferred onto white suburban children rather than the Negro "new kids." To complete the reversal, Rockwell painted the cat pearly white and put the animal into the hands of the black girl. He therefore re-inscribed popular notions of whiteness, as it had been associated with childhood innocence and moral purity, onto blacks. In effect, Rockwell took these connotations out of the exclusive province of white conceptions of self.

Rockwell's choice of young black children as the primary subject for two of his paintings is also significant in evoking shared humanity, even if the pictures of black youth may have reduced the severity of the situation in New Orleans and in the fictional white suburb to one of childhood naïveté, or served to emasculate black rage by substituting images of innocuous black children for images of politically engaged black agents. Moreover, the characters in Rockwell's paintings are slightly poster-like or cartoonish, and, as such, they might suggest either propaganda or a fantasy world where the "problem" of civil rights is easily resolved, as if the artist were merely cajoling or preaching, "Can't we all, white and black, just get along?" Despite these limitations, Rockwell was using a form of popular illustration with which he was most comfortable to reach out to mainstream audiences, reminding them of their own moral-democratic responsibilities in the context of the civil rights debate. Stated differently, Rockwell created a visual enthymeme for interpreting integration and civil rights, which tapped into white America's sense of itself as a tolerant nation. In answer to the question posed by Look about "How We Live," Rockwell visually 
demonstrated that, if whites were to remain true to American ideals, and, therefore, to themselves, they would have to generate justifications for accommodating blacks like Ruby. That is, they would have to find ways of living, respectfully, with African Americans.

For Rockwell, the key to making this an acceptable (if not morally appropriate) alternative was to show the things blacks and whites shared in common, despite the racial and other differences. This he did especially through the characterizations of Ruby and the "New Kids," all of whom appeared to embody ideals about education or play, as indicated by the innocuous collection of accoutrements the children carried by their sides. In both paintings, Rockwell used the familiar objects of middle-class Americana - schoolbooks, sporting equipment, pets, and modest homes framed with grassy lawns - as objects of identification, thereby naturalizing the movement of blacks into the mainstream of white American life. But even in "Murder in Mississippi," where the objects of middle-class Americana were replaced by a barren, lunar-like landscape, blacks and whites are urged to stand together against the problems of racism, as the civil rights workers do in the picture.

What strikes the viewer of these works, then, is not the imprint of federal control (despite the presence of federal marshals) or even violations to the Southern way of life. Rather, Rockwell illustrated the sameness or similarity of children - and then later, in "Murder in Mississippi," of adults - regardless of race, even as moral agents such as Ruby were clearly seen as different from other children. Rockwell appears to have been promoting, through visual rhetoric, identification across the racial divide in dealing with racism. The moral complexities of his subjects notwithstanding, these paintings demonstrated that, if a black person's piety was to remain secure in a (potentially) profane scene, it had to be made safe by the democratic imperative of all Americans to create space for human difference-but difference of degree, not kind. This point is underscored by the use of color, particularly in the skin tones of the children and the adult depicted in "New Kids." The shades of skin tone range from a deep brown on the legs and arms of the "black" children, to the duskier brown of their faces, to the slightly lighter shade of brown on the hands and face of the man (father? mover?) coming out of the moving van, to the ruddy face of the dark haired "white" boy, to the slightly lighter, albeit tan complexion of the other "white" boy, and finally to the gray-toned skin of the "white"girl. Skin color thus functions rhetorically as a kind of repetitive form in the painting, re-articulating the idea that human difference is about differences in degree not kind. So, the pictures contrasted stereotypes of blacks with what Rockwell pictured to be a human reality while emphasizing assimilation and accommodation, which he seemed to perceive as the only moral response by whites to the new policy of desegregation and the larger civil rights movement. As Larson and Hennessey argue, Rockwell "invented" America during a time of dramatic social, political, and economic change. "Part of Norman Rockwell's role was to make the new seem familiar." ${ }^{\text {"3 }}$ In the process, he revealed the otherness of blacks as non-threatening and morally inspiring. Moreover, Ruby, the black suburban children, and the black civil rights workers, as "other," became identifiable persons as opposed to racial stereotypes. 


\section{Creating Recognition through Particularity}

Rockwell used the particularity of Ruby and the civil rights workers, characters drawn from recent history, to visualize the harrowing nature of their real situations and the courageous manner in which they confronted them. His paintings reminded viewers that Brown v. the Board of Education did not suddenly-or even 10 years out - turn Americans into decent people but instead precipitated a near civil war between those who supported segregation and its opponents. Often, the opponents found themselves alone or under siege, as is well displayed in "The Problem" and "Murder in Mississippi.” As Coles points out, Ruby's ordeal, remarkable by virtue of her age, was all the more heroic because of its "singularity." Unlike "others in New Orleans and elsewhere, she was all alone as she encountered those daily mobs, and the people on the street hurling epithets knew it, because they persisted far longer than those who shouted at" girls attending other New Orleans public schools. ${ }^{34}$

In "The Problem," Rockwell managed to suggest the "singularity" of the African American predicament formally, through the construction of the painting. For instance, as Marling observes, the vulnerability of Ruby is suggested by her small size as compared to four burly federal marshals assigned to escort her to class. ${ }^{35}$ We would add that, despite being placed inside a protective square, lined front and back by the marshals who precede and follow her, Ruby's vulnerability is accentuated by her precise position within the square. While Ruby walks closely behind the marshals to her front, Rockwell painted a large gap between her and the marshals following behind, into which he also included the word "nigger" (at the time, a term used by many whites to describe blacks aggressively and condescendingly) and a splattered tomato reminding viewers of a blood stain, both of which stand out against the slate gray school wall that forms the background of the painting. Also, Rockwell situated Ruby along a rectilinear plane within the larger protective square, the connecting lines of which display the racial epithet and the bloody stain. That is, the concentric squares into which she was put might just as easily have represented a square target or a cage. Indeed, the position of the marshals behind her suggests that, despite being charged with the mission of protecting her, they did not want to get too close to Ruby and thus become targets themselves. Moreover, Ruby's gait, determined although slightly awkward, seems thwarted by the marshals to her front to whom she appears to be nestling up against for security, but who nonetheless seem to be cutting off her potential forward movement or escape.

We might also mention the anonymity of the marshals - the fact that Rockwell did not show us their heads. He therefore eliminated any personal information one might glean from their countenance and, consequently, intensified the sense of isolation and uncertainty Ruby must have been experiencing.

So, the painting asks: How safe in the schoolyard is Ruby, really? Who are these marshals and would they protect her? What might happen to Ruby once she ventured beyond the bounds of her escort, since the tomato was obviously thrown from outside the secure block and the inscription "KKK" appears just to the left of the first set of marshals? And, more generally, how much freedom and possibility is in fact 
open to blacks, even after an official end to segregation? In other words, the ominous nature of the picture's rather complex structure belies the uncomplicated idealism of its content. However, the singularity of Ruby's situation, as Rockwell depicted it, functions to re-emphasize her courage and the moral righteousness of her cause in the midst of overwhelming opposition and hatred, and to reveal the sharp contrast between Ruby's virtue and the cowardice of the large mob that assaulted a lone child.

A similar sense of isolation, peril, and cowardice is captured in "Murder in Mississippi" by the way in which the civil rights workers appear trapped on what looks, as mentioned earlier, like a lunar landscape, with demonic or alien shadows creeping toward them from the lower right corner of the picture. Like Ruby, the workers have no place to run, out-manned and outflanked by the murderous mob, although the defiant and morally superior stance of the one standing worker indicates they would not flee even if given the chance. Clearly, Rockwell is depicting a moral crusade on a par with events such as World War II, for the civil rights workers are possessed of the same rigid determination and moral righteousness that Rockwell painted into subjects from his war posters, such as "Let's Give Him Enough and On Time" from 1942. Here, he showed a bloodied soldier on the front line, his position about to be overrun, sitting at a machine gun firing his remaining bullets. The soldier, leaning forward, with no obvious thought of abandoning his bunker despite the encroaching hazards, is ultimately alone, his fate apparently sealed. In many ways, then, Ruby, the civil rights workers, and the soldier are identical-their determination and defiance, as indicated by the formal construction of Rockwell's paintings, signal the legitimacy of their cause.

Of course, critics might object that the way in which Rockwell positioned the civil rights workers evoked a particular brand of paternalism that tended to dominate "liberal" white-authored depictions of the time, which characterized Negroes as needing the care, protection, and assistance of honorable, heroic whites. Indeed, early commemorations of Abraham Lincoln cast him in god-like form as the Great Emancipator, with Negroes bowed in grateful submission around his feet. In Rockwell's painting, the black civil rights worker is on his knees, his injured body sagging against the standing figure of one of his white counterparts, who is looking, perhaps defiantly, certainly heroically, directly toward the killers. Rockwell could not know in which order these men were slain, but this rendering of the moment is suggestive. The difference in Rockwell's depiction of the relationship between black and white counterparts is that neither man is safe: the standing white worker can no more protect his black fellow activist from the alien forces that threaten them than he can himself. They are caught, alone, in the headlights of "Southern Justice," which, as this particular title of the painting so clearly indicates, means murder, even though it is not portrayed explicitly.

As mentioned, "New Kids" has an unsettling quality as well. As viewers we are led to assume, by the positioning of the black children closer to the furniture and to the house, that it is they and not the white children who are new to the neighborhood. The very presence of blacks in a white, middle-class suburb would have been unusual for the time and therefore depicted a contradiction between the American dream of 
freedom and the extreme isolation and anxiety faced by many blacks who sought a piece of this dream in the nation's segregated public spaces. The isolation is suggested, more specifically, by the fact that there are three whites and only two blacks, undoubtedly Rockwell's way of signifying the minority status of blacks, especially those who ventured into all-white neighborhoods. In addition, Rockwell painted a gap between the black children and their white neighbors, a gap intersected by a series of perpendicular lines - one vertical line formed by the back end of the moving van, which traverses another more horizontal line across the forward path of the black children. This was probably his way of indicating the glaring economic, political, and social disparities between the races during the middle 1960s - or the social distance yet to be made up even by blacks who were on equal economic footing with whites. The lines also present a predicament: Who would be the first person to cross these deeply entrenched racial divisions (the horizontal line crosses pavement) and what would be the result?

Yet the gap also raised the possibility that the white children, who stand near the street at the back end of the driveway, could nevertheless block the black kids from the rest of the neighborhood. Neither do we know whether the black children are moving in or, as a result of their isolation, being forced to move out, although the title of the painting suggests the former. And the way in which Rockwell positioned the puppy sitting at the foot of the oldest white child makes the viewer wonder if the dog is striking a sort of "let's play" pose or about to lunge at the cat held by the black girl. The image seems somewhat ambiguous: On the one hand, the ebullient youth of the dog and its owners underscores what David Hickey has called Rockwell's "faith in the young as the ground-level condition of democracy." ${ }^{36}$ In the picture, both a black and white child are holding baseball gloves, icons of what was considered at the time an all-American sport. In the context of the painting, the gloves appear to unite the group in terms of their mutual interests across racial differences and may echo the "let's play" stance of the dog. On the other hand, the image of the dog also evokes the troubling specter of white persecution of blacks, as when white police set full-grown dogs on crowds of black demonstrators during civil rights marches in the early 1960s.

The truth of this scene is not fully revealed because, in the mid-1960s, no one knew how the space between the subjects would, ultimately, be filled, although Rockwell certainly hoped the children would set a moral example for their parents by tolerating the presence of one another, without fear. In this sense, "New Kids" imagined for white audiences a "ground-condition of democracy" - a world of shared public space and racial harmony. But it also clearly demonstrated to white viewers that such a development depended, to a very large extent, on the courage of black citizens who were willing to enter into these segregated, public spaces at the risk of being treated as interlopers by white people like the viewers themselves.

It is also interesting to point out that "The Problem" and "New Kids" depicted exterior landscapes where the strict color line became increasingly difficult to enforce and where physical force became one of the major ways in which blacks were denied access to those spaces. While whites could make and enforce colored restrooms, waiting areas, entrances, and so on in contained spaces through means other than 
direct physical force, their attempts to do so in the world out-of-doors - in school yards and in suburban neighborhoods - created additional problems for them, some of which were dealt with through violent means. This is why artists and photographers in the early years of the civil rights movement focused primarily on public transportation since, according to Helen Shannon:

Trains, buses, and trolleys, unlike restricted restaurants, hotels and stores, were ironically some of the few public spaces of segregation that were actually occupied by both blacks and whites. As a result, the very arbitrary division of the races within a shared space illustrated the absurdity of this social construction. ${ }^{37}$

Representing cases of segregation in other public accommodations would have meant compellingly portraying the non-presence of blacks, a difficult task for Rockwell or any other artist. Instead, Rockwell's images of blacks and whites in public places were highly suggestive of the particular anxiety of blacks as they sought to enter into previously segregated "public" spaces.

Rockwell's pictures functioned rhetorically to foster patterns of identification, evoking emotional and other ways of being in the world as individuals faced the extreme exigencies of isolation and persecution. He demonstrated that Ruby's particular situation, and the particular situation of the civil rights workers and even the black suburbanites, represented the predicament of every person who facilitated dramatic change in a hostile environment. At the same moment, the pictures disclosed the moral character of people like Ruby and the young workers, therefore illustrating, especially to skeptical or ignorant white audiences, the perhaps unrecognized moral substance of the civil rights movement as a whole.

\section{Making Abstract Concepts Knowable}

Rockwell's civil rights paintings reveal additional significance, for they raised viewers out of their limited vision and forced them to see a world in which the daily challenges of democracy were unsettling and gritty. Some of this is indicated above in our discussion of caricatures and particularity. But the point becomes more pronounced once we consider in greater detail the content of Rockwell's paintings in relation to the trajectory of his career. The art critic Robert Hughes observes that Rockwell himself was "more American than apple pie, more American than the flag, gentler and more affirmative than Dad, and that was what the American public in the early 1950s wanted." 38 Hickey also points out that well before the 1960s, much of Rockwell's collection represented what he calls "democratic picture painting," where everyday activities were invested "with a sense of historical consequence" and democracy frequently progressed "in an untidy dance of disobedience and tolerance." 39 However, in pictures like "The Problem," Rockwell seemed to admit that the distance between the abstract concepts he had painted previously and the material reality he had largely ignored was much greater than most of his Look audience (or, for that matter, readers of the Saturday Evening Post) had been led to believe. As Claridge tells us, Rockwell's Look paintings "centered on the most radical 
kind of disharmony experienced in the United States, creat[ing] a dramatic counterstatement to his decades of illuminating cultural harmony." 40

We have been suggesting all along that the more politically-engaged turn Rockwell took in the 1960s imbued his civil rights paintings with moral authority, in part because they exposed, with similar narrative appeal, certain "radical disharmonies" and imposing sacrifices in American democracy that Rockwell had glossed over previously. So, for example, while Ruby looks in many ways identical to the happygo-lucky youth Rockwell had painted earlier in his career, her countenance reveals a tentativeness and her social mobility is obviously constrained within a threatening, chaotic scene. Importantly, Rockwell did not show Ruby situated securely in the classroom along with other tolerant white children. In fact, she turned out to be the only student in her class, was not allowed to eat in the school cafeteria, and stayed inside for recess. In other words, despite being admitted to William Frantz, Ruby was in many ways denied the sort of "public" education granted to white children, many of whom refused to attend after Ruby entered. This is why Rockwell could not depict a de-segregated American public school as a final and finally liberated destination, but rather as a point along the way of the slow and agonizing evolution of democracy. For him, the idea that Ruby would suddenly be free at William Frantz was a mere abstraction of democracy, like the happy settings he had conjured up in earlier works.

Similarly, the civil rights workers are defiant but they are also seen as the victims of savage reprisals, the likes of which defied higher conceptions of American democratic protest envisioned in Rockwell's previous works like "Freedom of Speech" from his "Four Freedoms" series, in which a lone dissenter speaks at a New England town hall meeting, without argument or harassment. Also, like many of Rockwell's earlier renditions of children, the subjects in "New Kids" are enjoying childhood, yet they also appear uncertain if not insecure about what the future holds for them qua children in the newly desegregated neighborhood of the post civil rights era.

Democratic tolerance, in short, appears in Rockwell's civil rights paintings as a tenuous state of affairs. As Hickey observes, "It is exactly this sense of history [and democracy] as tumult ... that makes Rockwell a very poor candidate for the position of conservative icon for which he is regularly nominated." ${ }^{41}$ His "devotional aura" for a simpler past is rendered in "loving detail," according to Hickey. But it "derives less from his reactionary tendencies than from the fact that he invariably portrayed the present as a historical moment, as if it were the past-or moving rapidly in that direction." 42

Rockwell's rendition of the severe hardships confronting Ruby and the civil rights workers, and the accommodations the white suburban kids needed to make, also dramatized the extent to which democracy requires sacrifice, the brunt of which sometimes falls on children. As Danielle S. Allen has observed in Talking to Strangers, sacrifice is "a democratic fact," a fundamental means by which democratic rights are achieved. ${ }^{43}$ Yet, for whatever reasons, citizens often remain unaware of this "fact." So, as Allen observes, photojournalism and other visual images are important rhetorical means of illustrating the moral challenges facing them. The famous photos of Elizabeth Eckford, for example, who, like Ruby, was subjected to angry white mobs 
calling for her lynching as she made her way to Central High School in Littlerock, Arkansas, on September 4, 1957, show us "yet another sacrifice of a daughter to solidify new promises and democratic contracts." 44

Rockwell's civil rights paintings were also morally authoritative precisely because, as curator Linda Pero observes, he was willing to risk "his legacy by doing these topical paintings. The works were upsetting to many of his followers because this wasn't the same Rockwell anymore." 45 Apparently, for Rockwell, the goal of interrogating abstract categories of what it meant for whites and blacks to be free and tolerant in America - categories he had helped to construct - was worth the gamble of losing patrons who otherwise remained blinded by racism or ignorance. This sort of introspection and self risk was admirable, as some of his fans clearly observed. At the same time, Rockwell was asking these viewers to address their own individual commitments to democracy, as these had been shaped, in particular, by Rockwell himself. For him, the decision to face these commitments during a difficult period in American history was a moral one, not just for the artist but for the viewer. $^{46}$

Hence, and most striking of all, rather than simply praising American democracy or portraying values like freedom and tolerance in reactionary ways, Rockwell's civil rights paintings raised for viewers the disturbing possibility that the good-natured, democratically-driven characters from previous works were not what they seemed. He appeared to be warning that the nurturing parent in "Thanksgiving: Mother and Son Peeling Potatoes," from 1945, for instance, or the gentle physician in "Doctor and Doll," of 1929, or the understanding police officer in "The Runaway," from 1958not to mention the collection of wholesome-looking townsfolk in "Saying Grace," from 1951 — could in real life have harbored racist, perhaps even violent sentiments and may eventually have supported or become members of the hostile white crowds in "The Problem" and "Murder in Mississippi." Confronting these innocuous figures from the past amounted not only to the re-conceptualization of popular American art but also to the dramatic reconsideration of whether the viewer's own democratic demeanor masked entirely un-democratic intentions.

Perhaps this is another reason why the heads of the marshals in "The Problem" are cropped and why the racial hatred to which Ruby is subjected is thrust into the canvas from the outside. The picture places white viewers into the role of the marshals while implicating them as members of the unseen hostile mob, as if to inquire: Were they, the viewers, also racists? And could they live up to the rugged demands of democracy, as the real-life marshals were being asked to do, or would they escape into the pleasures of middle-class affluence, as it was described in the pages of Look and depicted by Rockwell years before? As Sullivan-Sorin argues, unlike his earlier works Rockwell's civil rights paintings place us "in the position of facing the events head-on and examining our own prejudices. We are asked to consider our own involvement or passivity in the violence visited on some Americans by other Americans. Which side would each of us choose?" 47

Rhetoric functions to call forth the epistemic grounds upon which people base their everyday choices. By persuading viewers to make a choice-a choice Rockwell 
had apparently already made himself - these images appealed to a basic kind of knowledge that exists in the public sphere, one that allows people to "know" concepts such as freedom and democracy and the extent to which we take them for granted and are willing to sacrifice on their behalf. It is this knowing that visual rhetoric, in particular, appeals to by making things recognizable. The images make us recognizable to one another, providing the possibility of breaking out of the social realm of enforced norms and limited recognitions and into the realm where rhetorical efforts can achieve significance, even a shared public voice.

\section{Implications and Conclusions}

Rockwell's paintings seem to have evoked a wide variety of responses from the general public. As Claridge notes, many readers of Look reacted harshly to Rockwell's new paintings, while others emphasized knowledge made visible through images. In the case of "The Problem," "Black and white readers wrote to say that the painting said more than they could explain to their children or to themselves with words. And some of them wanted to go on record that this would prove a painting for the ages." 48 According to Adam Gorlick, "The Problem" "captured the country's attention" and "challenged his viewers to look at" racism and poverty. ${ }^{49}$ Gorlick quotes Ruby Bridges herself, who claimed the painting made her realize that her first day of school "was more than just a youngster's rite of passage," and succeeded as a "vehicle" for promoting tolerance and discouraging prejudice and racism. ${ }^{50}$ A more conservative but nonetheless revealing reaction is described in one of Robert Coles's interviews with a white person who had watched Ruby Bridges in New Orleans and also viewed Rockwell's picture. According to Coles, the onlooker conceded having learned something important about the humanity and the particularity of Ruby's plight:

That magazine tells you to "look," and I sure did; I thought "there she is, the nigra kid." You look at her and you begin to feel sorry for her-a lot of people will, I'm sure. It's not her we were against, you know. It's the interference in our life by those folks up North, that's what it was, that's what we were saying. ${ }^{51}$

This subject could not at the time make amends with the civil rights advocates from the "North," let alone understand his privileged position in relation to blacks. His response was still racist. However, the fact that Rockwell's painting had helped him to see Ruby as a "nigra" was important. As Coles explained, this term was "a less hostile or insulting or demeaning characterization - as opposed to the word 'nigger' which, heretofore, he'd all the time used." 52 "I couldn't help but feel then," Coles remarked, "that a magazine's picture had somehow touched his heart, had given him some psychological if not moral pause" by unveiling Ruby as a person and not merely a racial stereotype. ${ }^{53}$

These reactions reveal the power of rhetoric to create a truth and falsity that contradicts our basic "knowledge" of freedom and oppression. In earlier, idealized works such as the "Four Freedoms," Rockwell mostly praised Americans who had stood up for freedom and against oppression. However, the artist reminded viewers 
of his civil rights paintings of two disquieting facts: First, there existed a whole group of otherwise excluded African Americans who also deserved praise, many of whom were children; and second, prejudiced whites still oppressed blacks and, therefore, deserved only blame. In this way Rockwell's later pictures, by complicating viewers' understanding of American democracy, acted as dissoi logoi. They demonstrated that strong visual arguments could be produced for or against any widely accepted claim, even against the notion that Americans, on the whole, were free. Hence, Rockwell's images supplied hope by showing how visibility can provide access to a public voice for those previously denied access both by law and by practice, a voice that evokes the moral conscience of viewers.

At the dawning of the 21st century, however, we are saturated with images - not just paintings, but videotaped, computer-generated and -distributed, digital images, live, in real time, and always accessible. The result is that the power of individual visual images to transform our perspective and our deliberations seems diffused. This is the basis of Baudrillard's critique of post-industrial society. ${ }^{54} \mathrm{He}$ argues that contexts are simulated by the media and therefore have no referent, source, or ground. In addition, an excess of information is presented in a manner that precludes any response. Thus, the construction of public space is increasingly difficult to achieve. However, Richard Merelman argues that cultural artifacts and projections have come to dominate social and cultural debates, particularly those involving race. ${ }^{55}$ And Gunther Kress and Theo van Leeuwen, in their attempts to develop and articulate the principles behind multimodal communication, suggest that a shift has occurred in how we understand meaning. Rather than meaning being made once, they point out, multimodal resources available in a culture are "used to make meanings in any and every sign, at every level, and in any mode." 56 Thus, Rockwell's paintings not only made meaning for publics and their leaders in the context of the civil rights movement of the 1950s and 1960s, they have been digitized, enlarged, layered, reproduced, and recontextualized to make new meanings in shifting contexts. Indeed, Rockwell's "The Problem," several Life photographs about civil rights protests, and number of artistic renderings of the Selma march recently appeared in a special exhibit at the Smithsonian Museum on Washington, DC, called, "In the Spirit of Martin: The Living Legacy of Dr. Martin Luther King, Jr.," in which the images problematized King's legacy and the way in which he, and the civil rights movement he represented, are remembered and celebrated from the vantage point of the early 21st century. In addition, Rockwell's legacy from the 1960s was recently reexamined at the Norman Rockwell Museum in Stockbridge, Massachusetts, in an exhibit labeled, "Hometown Hero, Citizen of the World: Rockwell in Stockbridge." And "The Problem" has been included in Ruby Bridge's biography. Given these theoretical issues and the contemporary uses of Rockwell's work, we must speculate about the potential for visual images such as Rockwell's paintings to function rhetorically in civil rights commemoration.

Hariman and Lucaites' recent research into establishing the basis for what they refer to as "visual eloquence" provides one possible avenue for discussion. Through their analysis of individual photographs that enjoyed wide distribution and impact 
during the 20th century, such as the flag-raising at Iwo Jima, they seek to explicate a genre of visual rhetoric they refer to as iconic photographs. Hariman and Lucaites define iconic photographs as "photographic images produced in print, electronic, or digital media that are widely recognized, are understood to be representations of historically significant events, activate strong emotional response, and are reproduced across a range of media, genres or topics." 57 While the paintings analyzed above would seem to fit this definition, there are ways in which they differ markedly from the images analyzed by Hariman and Lucaites. Rockwell's paintings certainly elicited strong emotional responses, but unlike, say, the flag raising at Iwo Jima photograph, these emotions, for the most part, are specified: We see people's faces and we see them in their human particularity - we view them being vulnerable, courageous, scared, and confused in a visual form that is difficult to deny. As a result, rather than having a "lack of topical definition and a corresponding open emotionality that facilitate the metaphoric carryover from the specific historical moment to civic life in general," 58 these images are more topically and contextually bound. Yet because of this, they carry powerful ideological and commemorative potential, as if the images are frozen in time and yet begging for present viewers to ask: To what extent have the sacrifices of Ruby and the civil rights workers been redeemed in our own time? In what ways have significant middle-class, suburban housing gains been made for blacks today? Perhaps the prospect of confronting the images created by Rockwell's paintings, not only of African Americans but, by reflection, of the hateful white gangs, were too disturbing for many viewers. Such potential responses also seem to reflect a basic feeling about Rockwell's later pictures - they do not lie and cannot be contradicted.

Kress and van Leeuwen's work is also helpful here. They argue that multimodal discourses "not only provide versions of who does what, when and where" but also add "evaluations, interpretations and arguments" often "in a language that is to be lived as an identity building and identity confirming experience." 59 Therefore, whether visual images are part of the discourses of the civil rights movement or of its commemoration, part of a display at a museum or on a coffee mug, they are pedagogical tools. They communicate to the viewer, in the language of photography or painting or illustration or commemoration, the qualities, the pleasures or pain, the duties, the kind of past, present, and/or future that is or that is desired.

This pedagogical character of visual images leads to a final means of considering their rhetorical potential. In museums like the Smithsonian and the Norman Rockwell Museum, the epideictic role of visual images like the Rockwell paintings functions to praise those who continue to work on behalf of the values they make visible and blame those who do not. By signifying crucial points in the narrative of civil rights, these images display values that have either been betrayed or perpetuated; they link viewers to a moral narrative that has discontinued, progressed, or evolved in some (unexpected) fashion, while interrogating the viewer's own role in the narrative's development. These images instruct us as to who we are now as opposed to who we were then. They show which values ought to guide our deliberations. Indeed, once read in light of actual advances made by the civil rights movement, ordinary but politically un-involved viewers can come to recognize the profound 
political power of ordinary people like those portrayed in Rockwell's paintings, citizens engaging in ordinary deeds in the course of living. Thus, even though the focus is on people and events of the past, epideictic discourses of commemoration are really about the present - about asserting those things we should keep in memory and the values that will or ought to help us live in the present. ${ }^{60}$

Powell claims that much of the work about the civil rights movement originating from white artists reflected "the vantage point of the white homogenous selfrighteous 'We' of the title of Rockwell's painting," and that Rockwell, in particular, did not make it clear whether "the problem" resided in the evils of racism and bigotry or in an African American population no longer invisible and demanding civil rights. ${ }^{61}$ However, our analysis demonstrates that Rockwell's pictures remain rhetorically powerful, in that they are representations of historically significant events that activated and have the potential to activate strong responses. Those responses tend to be specified by both the visual content of the paintings themselves and by the discursive context in which they are placed. They are articulated and rearticulated, but always function pedagogically to teach us about what we value and/or ought to value. As a result their rhetorical potential to create an inclusive historical memory - to extend beyond the mere vantage point of "the white homogenous selfrighteous 'We"' of Rockwell's painting — remains strong. These images make parts of history visible, both practically and emotionally, and therefore attempt to outline the enormity of "The Problem" for both whites and blacks.

\section{Notes}

[1] David Halberstam, "Martin Luther King, American Preacher: He Delivered the Gospel According to the Constitution. Amen," Esquire, December 1983, 311. See also Gordon Parks, "Introduction: This Rare Collection," in Life: 100 Photographs That Changed the World (New York: Time, Incorporated Home Entertainment, 2003); W. Bitzhugh Brundage, "No Deed but Memory," in Where These Memories Grow: History, Memory, and Southern Identity, ed. W. Fitzhugh Brundage (Chapel Hill, NC: University of North Carolina Press, 2000), 22.

[2] Gretchen Sullivan-Sorin, "Martin Luther King, Jr. and the Enduring Struggle for Freedom," in In the Spirit of Martin: The Living Legacy of Dr. Martin Luther King, Jr., ed. Gretchen Sullivan-Sorin and Helen Shannon (Atlanta, GA: Tinwood Books, 2002), 17.

[3] Judy Larson and Maureen Hart Hennessey, "Norman Rockwell: A New Viewpoint," in Norman Rockwell: Pictures for the American People, ed. Maureen Hart Hennessey and Anne Knutson (New York: Harry N. Abrams, Inc., 1999), 43.

[4] Laurie Moffatt, “The People's Painter," in Norman Rockwell: Pictures for the American People, 26.

[5] Karal Ann Marling, Norman Rockwell (New York: Harry N. Abrams, Inc., 1997), 137.

[6] Laura Claridge, Norman Rockwell: A Life (New York: Random House, 2001), 449.

[7] Marling, Norman Rockwell, 140.

[8] Claridge, Norman Rockwell: A Life, 449.

[9] Marling, Norman Rockwell, 140.

[10] Lester C. Olson, "Portraits in Praise of a People: A Rhetorical Analysis of Norman Rockwell's Icons in Franklin D. Roosevelt's 'Four Freedoms' Campaign,” Quarterly Journal of Speech, 69 (1983): 24. Olson demonstrates how Rockwell painted scenes in which he synthesized symbols from diverse American populace, situations, and actions into each of the "Four 
Freedoms" so as to promote "varied identifications." While Olson provides a penetrating study of Rockwell's World War II illustrations, he does not examine the artist's civil rights pictures from the 1960s.

[11] Congressional debates over the Voting Rights Act in the early 1960s reveal that opponents of desegregation and the Civil Rights Act rhetorically depicted black people as a separate class of beings, interlopers into the territory of rights, and a physical and economic threat. Proponents rhetorically depicted black people as "the Negro" - a faceless, abstract concept - and placed most of their emphasis on the even more abstract concept of democracy and its related terms justice, fairness, and civil rights. Both sides denied Negroes any type of personhood, the result being that Negro men, women, and children were excluded or rendered invisible. See Hearings before the Committee on Rules, House of Representatives, Civil Rights, H.R. 7152, 88th Congress, 1964; and the interviews with Congressmen in "Crisis in Race Relations: How Will It Be Met?" U.S. News and World Report, August 10, 1964.

[12] "Quoted in Adam Gorlick, "Rockwell Left Nostalgia Behind," The News and Observer, June 6, 2004, 3G. Rockwell himself described this turn in the following manner: "There was a change in the thought climate in America brought on by scientific advances, the atom bomb, two world wars, Mr. Freud and psychology.... [I am] wildly excited about painting contemporary subjects ... pictures about civil rights, astronauts ... poverty programs. It's wonderful!" Quoted in David Hickey, "The Kids Are Alright: After the Prom," in Norman Rockwell: Pictures for the American People, 124. Perhaps the earliest and most obvious indication of Rockwell's desire to illustrate the civil rights movement occurred in "Freedom to Worship," in which he painted a black woman at prayer in the corner. According to Marling, the gesture convinced the head of the Bronx Inter-Racial Conference to ask Rockwell for a companion series on the subject of race relations in America, but the project never materialized. See Marling, Norman Rockwell, 138. A more recent example of Rockwell's interest in civil rights occurred in 1959, when Rockwell began imagining a 10-foot mural to symbolize the United Nations and the idea of world tolerance as expressed in "The Golden Rule." The early sketches received scant attention from various ambassadors and so Rockwell stored his preliminary work in a back room of his studio. In 1960, however, he decided to illustrate the maxim by painting a canvas with faces from all over the world, all in an attitude of worship. The painting, also called "The Golden Rule," appeared on the Saturday Evening Post cover of April, 1961. While not directly tied to the civil rights movement, the picture displayed a multi-cultural group of people arranged in a fashion that appeared to designate their order of appearance - and significance - in world history. Curiously, Jews and blacks shared dominant positions in the foreground of the painting. This suggested what would have been for many of his followers the radical idea that the descendents of all racial groups, including Caucasians, were Jews and blacks, one big "family of humans," as it were. On the other hand, at a more metaphorical level - and perhaps for those who took special umbrage at this unsettling idea-Rockwell indicated that all people were seen equally in the eyes of God, something he emphasized by writing in capital letters across the bottom third of the picture the words, "DO UNTO OTHERS AS YOU WOULD HAVE THEM DO UNTO YOU." Rockwell received the Interfaith Award of the National Conference of Christians and Jews for his picture. It described his work as "depicting the universal fact that all men ... are members of the One Family of Man under God." Eventually, the painting was hung in the United Nations building.

[13] Kathleen Hall Jamieson, Eloquence in an Electronic Age: The Transformation of Political Speechmaking, (New York: Oxford University Press, 1988), 56.

[14] Jamieson, Eloquence in an Electronic Age, 57.

[15] Elizabeth Grace Hale, Making Whiteness: The Culture of Segregation in the South, 1890-1940 (New York: Pantheon Books, 1998), 7 and 8. For a more recent investigation of patterns of 
racial depiction in the mass media, see Robert M. Entman, The Black Image in the White Mind: Media and Race in America (Chicago: University of Chicago Press, 2000).

[16] Hale, Making Whiteness, 8.

[17] Rockwell himself produced stultifying images of African Americans. For example "Boy in a Dining Car," from 1946, portrayed a scene on board the dining car of a train, where a black steward stands over, and is apparently amused by, a white child's determined effort to make sense of the check. As Hale might put it, the painting is significant because both the steward and the child appear visually unaware of their servant-master relationships as this configuration was determined by the racial conventions of the time. The picture, therefore, could be read as helping to increase the invisibility and power of whiteness. See also Marling's analysis of "condescending" racial stereotypes in Rockwell's lesser known work, "Love Ouanga," which American Magazine published in 1936 to accompany a Kenneth Perkins short story by the same name. Marling, Norman Rockwell, 137.

[18] Perkle Jones was quoted from the Tavis Smiley show, "Looking Back at the Panther Movement," on July 19, 2004, www:npr.org/templates/rundowns/rundown.php?prgId=14/.

[19] Hickey, "The Kids Are Alright," 124.

[20] Quoted in Robert Coles, "Ruby Bridges and a Painting," in Norman Rockwell: Pictures for the American People, 111.

[21] Robert Hariman and John Louis Lucaites, "Performing Civic Identity: The Iconic Photograph of the Flag Raising at Iwo Jima," Quarterly Journal of Speech 88 (2002): 365.

[22] Susanne Langer, Problems of Art (New York: Charles Scribner Sons, 1957), 31.

[23] Hariman and Lucaites, "Performing Civic Identity," 364.

[24] Michael Warner, "Publics and Counter Publics," Public Culture 14 (2002): 57.

[25] Harriman and Lucaites, "Performing Civic Identity," 365. Focusing specifically on Joe Rosenthal's famous photograph of marines hoisting an American flag on Iwo Jima, they argue that the picture's appeal arises from its embodiment of three discourses of political identity - egalitarianism, nationalism, and civic republicanism. For additional analysis of how visual images categorize racial identity in abstract terms, see Lauren R. Tucker and Hemant Shah, "Race and the Transformation of Culture: The Making of the Television Miniseries Roots," in Critical Studies in Mass Communication, 9 (1992): 325-36.

[26] Richard J. Powell, Black Art and Culture in the Twentieth Century (New York: Thames and Hudson, 1997), 118. We should note that while Rockwell's pictures show an imperfect world where desegregation might, at some juncture, have worked, many contemporary African American scholars argue that the civil rights movement and the Brown decision in particular never achieved their stated aims and in fact fell short by a wide margin. See, for example, Charles J. Ogletree, All Deliberate Speed: Reflections on the First Half-Century of Brown v. Board of Education (New York: Norton, W.W. and Company, Inc., 2004); Sheryll Cashin, The Failures of Integration: How Race and Class are Undermining the American Dream (Philadelphia: Perseus Books, 2004); and Derrick Bell, Silent Covenants: Brown v. Board of Education and the Unfulfilled Hopes for Racial Reform (New York: Oxford University Press, 2004).

[27] One example of how the white press perpetuated images of blacks as "threatening" appeared in the remarks of a Mississippi newspaper editorialist, who responded to the Brown v. the Board of Education Supreme Court decision by predicting that,

Human blood may stain Southern soil in many places because of this decision but the dark red stains of that blood will be on the marble steps of the United States Court Building. White and Negro children in the same schools will lead to miscegenation. Miscegenation leads to mixed marriages and mixed marriages lead to mongrelization of the human race. 
In Virginia, another writer regretted the general move toward racial desegregation in American society: "To many people this decision is contrary to a way of life and violates the way they have thought since 1619." For these and similar reactions to the Supreme Court decision on desegregation, see http://www.landmarkcases.org/brown/reaction.html.

[28] Coles, "Ruby Bridges and a Painting," 105.

[29] Coles, "Ruby Bridges and a Painting," 105.

[30] Coles, "Ruby Bridges and a Painting," 109 (his emphasis).

[31] For an examination of the ways in which black authors wrestled with the sources of racial conflict, see William Ryan, Blaming the Victim (New York: Knopf Publishing Group), 1976.

[32] Claridge, Norman Rockwell: A Life, 451-52.

[33] Larson and Hennessey, "Norman Rockwell: A New Viewpoint," 50. Hickey also suggests that Rockwell celebrated acts of tolerance in his paintings "because in a democracy where everyone is different and anything can happen, tolerance is the overriding social virtue." See Hickey, "The Kids Are Alright," 125.

[34] Coles, "Ruby Bridges and a Painting," 107.

[35] Marling, Norman Rockwell, 140.

[36] Hickey, "The Kids Are Alright," 120.

[37] Helen M. Shannon, "Watching History-Making in the Making," in In the Spirit of Martin: The Living Legacy of Dr. Martin Luther King, Jr., 22.

[38] Robert Hughes, American Visions: The Epic History of Art in America (New York: Alfred A. Knopf, 1999), 509.

[39] Hickey, "The Kids Are Alright," 125 and 128. Moffatt adds that Rockwell's images "convey our shortcomings as well as our national ideals of freedom, democracy, equality, tolerance, and common decency in ways that anybody could understand." See Moffatt, "The People's Painter," 26.

[40] Claridge, Norman Rockwell: A Life, 449-50.

[41] Hickey, "The Kids Are Alright," 125. Whereas before Rockwell had concentrated on portraying what Hickey calls a world in which only "the minimum conditions of democracy are made visible," his civil rights pictures revealed that not even the "minimal" conditions had been established where blacks were concerned, at least not in Louisiana or Mississippi or in segregated white suburbs (125).

[42] Hickey, "The Kids Are Alright," 125 (his emphasis).

[43] Danielle S. Allen, Talking to Strangers: Anxieties of Citizenship since Brown v. Board of Education (Chicago: University of Chicago Press, 2004), 25-52.

[44] Allen, Talking to Strangers, 39.

[45] Quoted in Adam Gorlick, "Rockwell Left Nostalgia Behind," The News and Observer, June 6, 2004, 3G.

[46] Rockwell's decision amounted to what Marling has called "a confession of his own sins." She goes on to quote Rockwell himself, who admitted, "I was born a white Protestant with some prejudices which I am continuously trying to eradicate.... I am angry at unjust prejudices, in other people or myself." Marling, Norman Rockwell, 140.

[47] Sullivan-Sorin, "Martin Luther King, Jr. and the Enduring Struggle for Freedom," 76.

[48] Claridge, Norman Rockwell: A Life, 452.

[49] Gorlick, "Rockwell Left Nostalgia Behind," 3G.

[50] Quoted in Gorlick, "Rockwell Left Nostalgia Behind," 3G. For an account of her experiences at William Frantz, see Ruby Bridges, Through My Eyes, ed. Margo Lundell (New York: Scholastic Press, 1999).

[51] Coles, "Ruby Bridges and a Painting," 111.

[52] Coles, "Ruby Bridges and a Painting," 111.

[53] Coles, "Ruby Bridges and a Painting," 111. Of course, the irony here is that this man's comments reveal the extent to which "the problem" was and is in the hearts and minds of white Americans, as Rockwell and black leaders such as Stokely Carmichael argued: 
I maintain that every civil rights bill in this country was passed for white people, not for black people. For example, I am black. I know that. I also know that while I am black, I am a human being. Therefore I have the right to go into any public place. White people didn't know that. Every time I tried to go into a public place they stopped me. So some boys had to write a bill to tell that white man, "He's a human being; don't stop him." That bill was for the white man, not for me. I knew I could vote all the time and that it wasn't a privilege but a right.... That bill was for white people. I know I can live any place I want to live. ... You need a civil rights bill, not me. The failure of the civil rights bill isn't because of Black Power or because of the Student Nonviolent Coordinating Committee or because of the rebellions that are occurring in the major cities. That failure is due to the whites' incapacity to deal with their own problems inside their own community.

In James Andrews and David Zarefsky, Contemporary American Voices: Significant Speeches in American History, 1945-Present (New York: Longman Publishing Group, 1999), 102.

[54] Mark M. Poster, Jean Baudrillard: Selected Writings (Stanford, CA: Stanford University Press, 1988), 7.

[55] Richard Merelman, Representing Black Culture: Racial Conflict and Cultural Politics in the United States (New York: Routledge, 1995).

[56] Gunther Kress and Theo van Leeuwen, Multimodal Discourse: The Modes and Media of Contemporary Communication (London: Arnold Publishers and New York: Oxford University Press, 2001), 4.

[57] Hariman and Lucaites, "Performing Civic Identity," 366.

[58] Hariman and Lucaites, "Performing Civic Identity," 381.

[59] Kress and van Leeuwen, Multimodal Discourses, 22.

[60] As Kenneth Burke writes, "[If] in the opinion of a given audience, a certain kind of conduct is admirable, then a speaker might persuade the audience by using ideas and images that identify his cause with a kind of conduct." Kenneth Burke, A Rhetoric of Motives (Berkeley: University of California Press, 1969), 5.

[61] Powell, Black Art and Culture in the Twentieth Century, 119. 
Copyright of Quarterly Journal of Speech is the property of National Communication Association. The copyright in an individual article may be maintained by the author in certain cases. Content may not be copied or emailed to multiple sites or posted to a listserv without the copyright holder's express written permission. However, users may print, download, or email articles for individual use. 